\title{
Pharmaceutical Dosage Form
}

National Cancer Institute

\section{Source}

National Cancer Institute. Pharmaceutical Dosage Form. NCI Thesaurus. Code C42636.

The form in which active and/or inert ingredient(s) are physically presented. 